\title{
Implemetasi Pada Guru/Pegawai di SMA Negeri 12 Pekanbaru Dengan Metode Tes Uji Rinne Pada Remaja Gangguan Pendengaran Dengan Penggunaan Handphone
}

\author{
Chairil, Ratih Oktaviani \\ Program Studi Keperawatan, Universitas Muhammadiyah Riau \\ Coresspondence Email : chairil@umri.ac.id
}

\begin{abstract}
Mobile phone is one of the developing communication tools today. The global debate and controversy regarding the health effects of cell phones continues. There are concerns that radio frequency energy (radio waves) emitted can cause health problems, especially to hearing function. The aim of the study was to find out how "the description of hearing loss with the use of mobile phones in Pekanbaru 12 SMA. The type of research used is descriptive with probality sampling sampling technique where the sample in this study is to take respondents based on random or coincidental in SMA Negeri 12 Pekanbaru which amounted to 249 respondents. Data collection tools using questionnaires as well as examination of auditory function by means of the rinne test used is univariate. The results of the research which was conducted on 23 July - 28 July 2018 showed that of 249 respondents (100\%) were all mobile users and from the results of rinne test, 66 respondents (26.5\%) had positive hearing loss and 183 respondents $(73,5 \%)$ negative did not experience hearing loss.
\end{abstract}

Keywords: Mobile phone, hearing loss, rinne test.

\section{Abstrak}

Handphone adalah salah satu alat komunikasi yang sedang berkembang saat ini.Perdebatan dan kontroversi secara global mengenai efek kesehatan dari telepon seluler terus berlanjut.Ada kekhawatiran bahwa energi frekuensi radio (gelombang radio) yang dipancarkan dapat menyebabkan masalah kesehatan, terutama terhadap fungsi pendengaran. Tujuan dari Pengbadian program kemitraan masyarakat stimulus memberikan arahan konsep pengunaan hp yang tidak berlebihan waktunya pada remaja yang berada di SMA12 pekanbaru , kerena dapat beresiko mengalami Gangguan Pendengaran metode pendengaran dengan cara tes uji rinne yang digunakan adalah univariate. . Hasil dari pengabdian ini diharapakna guru/pegawai mengunakan metode uji rinne dan memberikan arahan pada remaja di SMA 12 Pekanbaru dalam pengunaan hp dan aturan-aturanya . yang telah dilaksanakan pada tanggal 23 juli - 28 juli 2018 menunjukkan bahwa dari 249 responden (100\%) seluruhnya merupakan pengguna handphone dan dari hasil pemeriksaan uji rinne didapatkan 66 responden $(26,5 \%)$ positif mengalami gangguan pendengaran dan 183 responden (73,5\%) negatif tidak

Received: 9 Agust 2020, Accepted : October 2020 - Jurnal Photon Vol.11 No.1

DOI : https://doi.org/10.37859/jp.v11i1.2096

PHOTON is licensed under a Creative Commons Attribution-ShareAlike 4.0 International License 
mengalami gangguan pendengaran..dengan Penggunaan Handphone di SMA Negeri 12 Pekanbaru. Jenis Penelitian yang digunakan adalah deskriptif dengan tehnik pengambilan sampel probality sampling dimana sampel dalam penelitian ini adalah mengambil responden berdasarkan acak atau kebetulan yang ada di SMA Negeri 12 Pekanbaru yang berjumlah 249 responden. Alat pengumpulan data menggunakan kuesioner serta pemeriksaan fungsi pendengaran dengan cara tes uji rinne yang digunakan adalah univariate. Hasil Penelitian yang telah dilaksanakan pada tanggal 23 juli - 28 juli 2018 menunjukkan bahwa dari 249 responden (100\%) seluruhnya merupakan pengguna handphone dan dari hasil pemeriksaan uji rinne didapatkan 66 responden $(26,5 \%)$ positif mengalami gangguan pendengaran dan 183 responden (73,5\%) negatif tidak mengalami gangguan pendengaran..

Kata Kunci : Handphone, gangguan pendengaran, tes uji rinne

\section{Introduction}

Telepon selular atau biasa juga disebut handphone adalah salah satu alat komunikasi yang sedang berkembang saat ini. Perdebatan dan kontroversi secara global mengenai efek kesehatan dari telepon seluler terus berlanjut. Ada kekhawatiran bahwa energi frekuensi radio (gelombang radio) yang dipancarkan dapat menyebabkan masalah kesehatan, terutama terhadap fungsi pendengaranTelepon seluler harus memancarkan energi frekuensi radio pada tingkat yang cukup tinggi untuk mencapai Base Transceiver Station (BTS) menara antena. Dalam hal ini gelombang radio (micro-wave) yang dipancarkan secara langsung ke kepala pengguna, menyebabkan keamanan teknologi ini diragukan Ada kekhawatiran bahwa energi frekuensi radio (gelombang radio) yang dipancarkan dapat menyebabkan masalah kesehatan, terutama terhadap fungsi pendengaran. Tujuan dari Pengbadian program kemitraan masyarakat stimulus memberikan arahan konsep pengunaan hp yang tidak berlebihan waktunya pada remaja yang berada di SMA12 pekanbaru, kerena dapat beresiko mengalami Gangguan Pendengaran metode pendengaran dengan cara tes uji rinne yang digunakan adalah univariate. . Hasil dari pengabdian ini diharapakna guru/pegawai mengunakan metode uji rinne dan memberikan arahan pada remaja di SMA 12 Pekanbaru dalam pengunaan hp dan aturan-aturannya . Menurut studi dari Schörnborn et alpada tahun 2009 yang dikutip dari Romanian J. Biophys, menunjukkan bahwa kepala orang dewasa menyerap 80 persen dari radiasi yang dipancarkan oleh telepon seluler (Supit, 2013).

Peningkatan besar dalam penggunaan telepon seluler di seluruh dunia per Juni 2009 terdapat lebih dari 4,3 miliar pengguna di seluruh dunia.Menurut laporan Inter-national Telecommunication Union (ITU) 2010 yang dikutip dari Institute for Policy Research Northwestern University, jumlah pengguna telepon seluler di Amerika Serikat bertambah dari 184,8 juta pada 2004 dan meningkat menjadi 298,4 juta pada tahun 2009 (Battung, 2013).

Received: 9 Agust 2020, Accepted : October 2020 - Jurnal Photon Vol.11 No.1

DOI : https://doi.org/10.37859/jp.v11i1.2096

PнотОN is licensed under a Creative Commons Attribution-ShareAlike 4.0 International License 


\section{The Methods}

Penelitian ini menggunakan metode deskriptif.Metode deskriptif merupakan salah satu dari jenis jenis metode penelitian.Metode deskriptif adalah metode penelitian yang dilakukan dengan tujuan untuk membuat gambaran atau deskripsi tentang suatu keadaan secara objektif (Notoatmojo, 2005).

Dimana dalam penelitian ini peneliti melakukan aplikasi dengan membagikan kuisioner yang harus di jawab responden dan melakukan tes uji pendengaran yaitu tes uji rinne menggunakan alat garputala untuk mengetahui hasil positif atau negatif pada siswa dan siswi di SMA Negeri 12 Pekanbaru tentang gangguan pendengaran dengan penggunaan handphone.

\section{Result and Discussion}

Bedasarkan hasil penelitian yang dilakukan peneliti pada tanggal 23 Juli sampai dengan 28 Juli 2018 di SMA Negeri 12 Pekanbaru dengan judul “Deskripsi Gangguan Pendengaran dengan Penggunaan Handphone pada Remaja di SMA Negeri 12 Pekanbaru”. Menurut hasil yang diperoleh dari penelitian ini dinyatakan bahwa responden yang menggunakan handphone sebanyak 249 responden (100\%), sedangkan dari hasil pemeriksaan tes uji rinne didapatkan 66 responden (26,5\%) positif mengalami gangguan pendengaran dan 183 responden $(73,5 \%)$ negatif mengalami gangguan pendengaran.

Penelitian dari Oktay dan Dasdag yang dikutip dari Bahrain Medical Buletin, dan dipresentasikan pada Pertemuan Tahunan American Academy of Otolaryngology-Head and Neck Surgery, 100 orang yang telah menggunakan telepon seluler selama lebih dari setahun mengalami peningkatan derajat gangguan pendengaran selama rentang 12 bulan. Studi ini menemukan bahwa orang yang menggunakan telepon seluler lebih dari 60 menit sehari memiliki ambang pendengaran yang lebih buruk daripada mereka yang menggunakannya kurang dari itu, selain itu orang yang menggunakan telepon seluler selama lebih dari satu jam per hari merasa sulit untuk membedakan suara frekuensi tinggi (misalnya s, f, h, t, dan z) pada awal kata (Al-Abduljawad, 2008).

Dari penelitian diatas berkesinambungan dengan hasil penelitian saya, dimana dari 66 responden $(26,5 \%)$ yang positif mengalami gangguan pendengaran dari hasil jawaban kuisioner juga memilih jawaban kuisioner sering menelfon lebih dari 30 menit setiap harinya.

Received: 9 Agust 2020, Accepted : October 2020 - Jurnal Photon Vol.11 No.1

DOI : https://doi.org/10.37859/jp.v11i1.2096

PHOTON is licensed under a Creative Commons Attribution-ShareAlike 4.0 International License 


\section{Conclusion}

Gangguan pendengaran berbeda dengan ketulian, gangguan pendengaran (hearing impairments) adalah gangguan pada organ pendengaran (telinga) seseorang sehingga kualiti kemampuan mendengar orang tersebut menjadi lemah apabila dibandingkan dengan orang lain yang normal (Wekke, 2015).

Berdasarkan hasil penelitian yang dilakukan di SMA Negeri 12 Pekanbaru pada tanggal 23 Juli sampai 28 Juli 2018 dengan cara menyebarkan lembar kuisioner yang berisikan 10 pernyataan sesuai dengan masalah yang diteliti, serta tes uji rinne maka dapat disimpulkan, bahwa remaja yang diteliti merupakan kelas X dan XI dengan hasil analisis didapatkan ratarata umur remaja umur termuda 15 tahun dan umur tertua 18 tahun.

Dari jumlah responden yang berjumlah sebanyak 249 responden (100\%) semuanya merupakan pengguna handphone, dan 249 responden (100\%) juga pengguna handphone jenis android. Dan dari hasil tes uji rinne di dapatkan hasil 66 responden positif dan 183 responden negatif.

\section{References}

Ali, Iskandar. (2016). Mengatasi Gangguan pada Telinga dengan Tanaman Obat.Penerbit : Agro Media.

Fadilah, Ahmad. (2011). Pengaruh Penggunaan Alat Komunikasi Handphone (HP) Terhadap Aktivitas Belajar Siswi MMP Negeri 66 Jakarta selatan. Jurnal Penelitian.

Hidayat.A.A.A. (2007).Riset Keperawatan dan Teknik Penulisan Ilmiah. Jakarta: Salemba Medika.

Hurlock, Elizabet B. (2008) Psikologi Perkembangan. Alih bahasa: Dra Ishwidayati. Edisi V. Jakarta: Erlangga.

Idayati, Ratna. (2011). Pengaruh Radiasi Handphone terhadap Kesehatan. Jurnal Kedokteran Syiah Kuala.

Irdandi, Alfian. Helfi, Nasution \& Anggi, Srimurdianto.(2017). Perancangan Aplikasi Multimedia Untuk Pengenalan Bahasa Isyarat Bagi Anak Tunarungu Berbasi Android. Jurnal Sistem dan Teknologi Informasi.

Kaplan, HI. Benjamin, JS. Jack, AG. (2010). Gangguan mood dalam. Dalam:synopsis psikiatri ilmu pengetahuan perilaku psikiatri.Edisi 7.jilid 1.Jakarta : Binarupa Aksara.

Kustiawan, Usep. (2016). Pengembangan Media Pembelajaran Anak Usia Dini.Penerbit : Gunung Samudra.

Received: 9 Agust 2020, Accepted : October 2020 - Jurnal Photon Vol.11 No.1

DOI : https://doi.org/10.37859/jp.v17i1.2096

PHOTON is licensed under a Creative Commons Attribution-ShareAlike 4.0 International 
Ludmad, Harold. (2014). Petunjuk Penting pada Penyakit Telinga Hidung Tenggorokan.Penerbit: Buku Kedokteran EGC.

Notoatmodjo, S. (2012).Metedologi Penelitian Kesehatan. Jakarta: Rineka Cipta

O. Battung, Rut. Jimmy F, Rumampuk \& Wenny, Supit.(2013). Hubungan Radiasi Gelombang Elektromagnetik Telepon Seluler Terhadap Fungsi Pendengaran Mahasiswa Angkatan 2009 Fakultas Kedokteran Universitas Sam Ratulangi Manado.Jurnal e-Biomedik.

Rahma, Afifah, 2015. Hal 3. Pengaruh Penggunaan Smartphone Terhadap Aktifitas Kehidupan Siswa (Studi Kasus MAN 1 Rengat Barat).Fakultas Ilmu Sosial Dan Ilmu Politik Universitas Riau.

Rahman, Sukri. (2015). Deteksi \& Solusi Gangguan Pendengaran dalam Meningkatkan Kualitas Hidup (Tingkat Layanan Kesehatan Primer sampai Tersier).Penerbit : Bagian THT-KL Fakultas Kedokteran Universitas Andalas. Padang.

Rahmawati, Dini. (2015). Faktor-Faktor yang Berhubungan dengan Gangguan Pendengaran pada Pekerja di Dapertemen Metal Forming dan Heat Treatment PT. Dirgantara Indonesia (PERSERO). Jurnal Penelitian.

R. Thaller, Seth. (2008). Diagram Diagnostik Penyakit Telinga Hidung Tenggorokan.Penerbit : Buku Kedokteran EGC.

Tamher.S \& Noorkasiani. (2009). Kesehatan Usia Lanjut dengan Pendekatan Asuhan Keperawatan.Penerbit : Salemba Medika

Wijayakusuma, Hembing. (2008). Bebas Diabetes Mellitus Ala Hembing.Penerbit : Puspa Swara.

Y. Widyawati, Ika. (2012). Manual Prosedur Pemeriksaan Fisik pada Telinga. Fakultas Keperawatan Universitas Airlangga. Keperawatan Sensori Persepsi

Received: 9 Agust 2020, Accepted : October 2020 - Jurnal Photon Vol.11 No.1

DOI : https://doi.org/10.37859/jp.v17i1.2096

PHOTON is licensed under a Creative Commons Attribution-ShareAlike 4.0 International 